\title{
What Drives Corporate Tax Rates Down? A Reassessment of Globalization, Tax Competition, and Dynamic Adjustment to Shocks
}

\author{
MICHAEL OVERESCH \\ JOHANNES RINCKE
}

CESIFO WORKING PAPER NO. 2535

CATEgORY 1: Public FinANCE

FEBRUARY 2009
An electronic version of the paper may be downloaded
- from the SSRN website:
- from the RePEc website:
- from the CESifo website:
www.SSRN.com
www.RePEc.org
www.CESifo-group.org/wp




\title{
What Drives Corporate Tax Rates Down? A Reassessment of Globalization, Tax Competition, and Dynamic Adjustment to Shocks
}

\begin{abstract}
We reassess the driving forces behind the recent decline of corporate tax rates in Europe. Using data for up to 32 countries from 1983 to 2006, we analyze the role of economic and financial openness as well as tax competition while allowing for dynamic adjustment to shocks and period-specific as well as country-specific effects. While openness does not seem to be systematically related to corporate tax rates, our findings suggest that countries compete over statutory tax rates. In contrast, we do not find competition over effective marginal rates. While the short-run impact of tax competition on corporate tax rates seems to be modest, the interplay of tax competition and a sluggish adjustment of tax rates over time implies that permanent shocks to individual countries have substantial long-run effects on equilibrium tax levels in all countries.
\end{abstract}

JEL Code: H20, H25, H71.

Keywords: corporate taxes, tax competition, openness.

Michael Overesch
Centre for European Economic Research
(ZEW), L7,1
68163 Mannheim
Germany
overesch@zew.de

\author{
Johannes Rincke \\ University of Munich \\ Department of Economics \\ Seminar for Economic Policy \\ Akademiestrasse 1/II \\ 80799 Munich \\ Germany \\ johannes.rincke@lrz.uni-muenchen.de
}

January 2009

We would like to thank Peter Egger, Andreas Haufler, Johannes Voget, and the participants of the CESifo Area Conference on Public Sector Economics in Munich, of the CESifo Venice Summer Institute 2008, and of the Congress of the German Economic Association (VfS) in Graz for their comments and George M. Korniotis for providing Gauss code. The usual disclaimer applies. The second author gratefully acknowledges the hospitality of the Carnegie Mellon University and the Universitat Pompeu Fabra and financial support by the German Research Foundation (DFG). 


\section{Introduction}

Over the past 25 years, corporate tax rates in Europe show a remarkable downward trend. In 1983, the mean statutory corporate tax rate of 13 Western European countries accounted to $49.2 \%$. As of 2008 , the average tax rate of these countries had eroded to $27.2 \%$. Despite the fact that it may significantly affect the ability of national governments to run independent fiscal policies, no unified approach to determine the driving forces behind the decline of corporate tax levels has emerged.

Two mostly independent strands of literature have dealt with the determinants of corporate taxes. The first one asks whether the increasing openness of economies, in particular the enhanced mobility of capital, leads to lower corporate tax rates. Slemrod (2004) uses a discrete indicator of trade openness and finds a negative impact of trade openness on the statutory company tax rate. Similarly, Rodrik (1997) as well as Winner (2005) provide evidence suggesting that higher capital mobility is associated with lower company tax rates. The finding that governments in more open economies set lower taxes on corporate income is also supported by studies using some index of the degree of liberalization of international capital transactions to measure openness such as Swank and Steinmo (2002) and Schwarz (2007).

A second strand of literature models governments as agents behaving strategically when setting their tax policies. This gives rise to tax reaction functions describing optimal responses to tax policies of competing countries. For positively sloped 
reaction functions, governments will find it optimal to reduce their tax rates in reaction to tax cuts by competitors. Consequently, the tax competition literature has asked whether the strategic interaction among governments can explain the decline of corporate tax rates in Europe as a 'race to the bottom', fuelled by individual governments' incentives to lure investors by competitive tax policies. In a recent study, Devereux et al. (2008) find support for the tax competition hypothesis for a sample of OECD countries, and other contributions have come to similar conclusions (Redoano, 2007; Egger et al., 2007; Davies and Voget, 2008).

Compared to the contributions discussing the role of economic and financial openness, the tax competition literature is methodologically more involved. Most studies try to identify the tax competition effect from a static model capturing the interdependency of national tax policies by a spatial lag of other countries' tax rates. However, the resulting endogeneity problem has been found difficult to solve, in particular because of a lack of convincing instrumental variables. Moreover, the static tax competition model ignores the fact that national tax policies are often characterized by substantial inertia, and that the evolution of corporate tax rates for individual countries as well as for the European average seems to be driven by a sluggish adjustment to shocks.

The contribution of thus study is twofold. Firstly, it provides a synthesis of previous research by carefully investigating the role of economic or financial openness and strategic tax competition in an integrated framework. Secondly, we allow for a dynamic adjustment of tax rates to tax policies of competing countries as well as 
to general economic shocks. This enables us to distinguish between strategic (shortrun) tax competition effects and long-run effects working through the interplay of direct tax competition and the sluggish adjustment of taxes over time. All this is done while netting out country-specific as well as period-specific effects. Hence, in contrast to most related studies, we fully separate common shocks potentially affecting tax policies in all countries from the country-specific and time-variant effects of interest.

Our data set covers up to 32 countries from 1983 until 2006, which is by far the most comprehensive data among all available studies on corporate taxation in Europe. To investigate the role of openness, tax competition, common shocks, and dynamic adjustment on corporate tax setting we estimate a series of panel data models, ranging from one allowing only for country-specific and period-specific effects to a dynamic model accounting for openness, tax competition and further controls. Our main findings are the following. First of all, economic or financial openness do not contribute to explaining corporate tax rates once we allow for more general specifications. In contrast, competition over statutory tax rates is found to significantly affect national tax policies. Since current rates are strongly affected by past levels, the moderate short-run effects of tax competition contribute to substantial multiplier effects for permanent changes in exogenous characteristics. For instance, in a stylized two-country example, the results of our dynamic fixed effects estimation would predict a decrease of the percentage of the population below 15 years by one percentage point in one country to have the following effects: 
in the short run, the statutory tax rate in the affected country will be reduced by about 0.44 percentage points. In the long run, however, the model predicts a reduction by 1.73 percentage points. Moreover, our model predicts that tax competition transmits the tax-reducing effect of the original shock to the other country. In the long run, even if its exogenous characteristics are unchanged, this country will reduce its own tax rate by 0.58 percentage points.

Taken together, these findings suggest that neither increased openness nor stronger competition for capital have caused the recent decline of corporate tax rates. Rather, it seems that changes in fundamental variables and permanent shocks like, for instance, the integration of the former communist countries of Eastern Europe, have been the ultimate forces driving down corporate tax rates. In a dynamic framework, the important role of tax competition turns out to be that it affects the long-run multipliers of permanent shocks. Hence, if the most relevant shocks to the fundamental variables are such that they tend to depress corporate tax rates, the presence of tax competition among countries will contribute to lower long-run equilibrium tax levels. Until the system has fully adjusted to the new equilibrium, the model predicts a steady decline of average tax rates and substantial heterogeneity among countries: while countries directly affected by shocks are predicted to cut their taxes sharply, unaffected countries should reduce their rates at a slower pace. This prediction seems to be well in line with the actual tax setting behavior of national governments in Europe. For instance, after the breakdown of the communist regimes in Eastern Europe in 1989, the Western European countries 
located at the former border between Western and Eastern Europe reduced their statutory tax rates significantly more than countries less directly affected by the integration shock. By the year 2000, the different pace in terms of rate cutting tax reforms between border and non-border countries amounted to a relative reduction of statutory rates in border countries of about 10 percentage points (Overesch and Rincke, 2009).

The remainder of the paper is organized as follows. In Section 2, we discuss recent trends in corporate tax rates in Europe. The estimation approach and the data are discussed in Section 3. Section 4 presents the results, and Section 5 concludes.

\section{Trends in corporate taxation in Europe}

Figure 1 summarizes the trends in corporate taxation in Europe since 1983. In the top left-hand panel, the graph shows the statutory corporate tax rate $(S T R)$. This is the statutory headline rate of the corporate income tax adjusted for surcharges and the average of local income tax rates. Furthermore, the figure shows cross-country averages for the effective marginal tax rate $(E M T R)$ and the effective average tax rate $(E A T R)$. The effective tax rates are calculated following Devereux and Griffith (2003). Unlike the statutory tax rate, effective tax rates reflect all relevant income and non-income taxes imposed on corporate investments as well as all rules affecting the tax base. ${ }^{1}$

\footnotetext{
${ }^{1}$ We refer the reader to Section 3.3 for a detailed description of effective tax rates.
} 
Figure 1: Trends in corporate taxation in Europe, 1983-2006

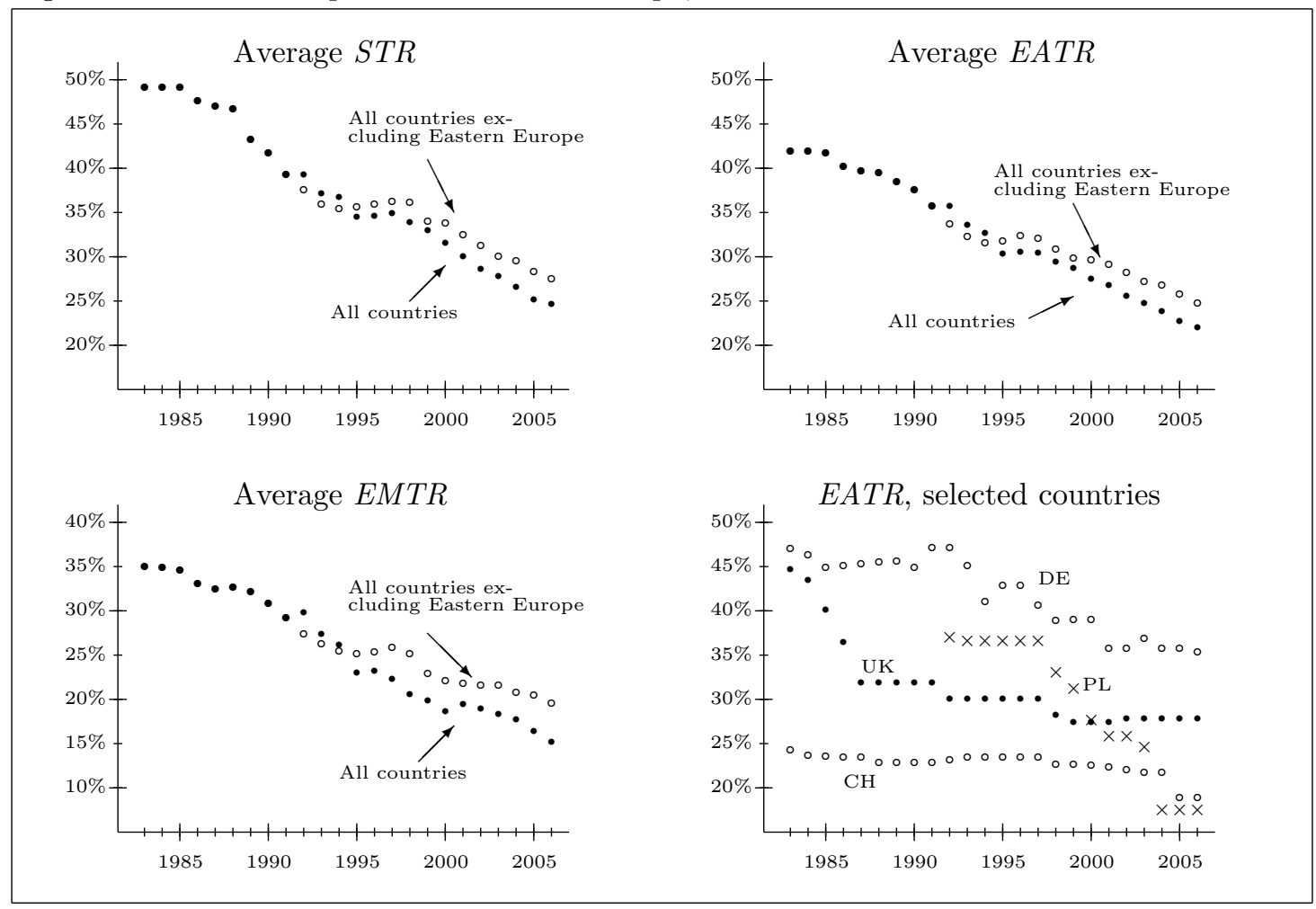

Graphs for average tax rates show unweighted averages. Countries in sample (period) are: Austria (83-06), Belgium (83-06), Switzerland (83-06), Cyprus (91-06), Denmark (83-06), Spain (91-06), Finland (83-06), France (83-06), Germany (83-06), Greece (90-06), Ireland (83-06), Iceland (9006), Italy (83-06), Luxembourg (83-06), Malta (94-06), Netherlands (83-06), Norway (90-06), Portugal (90-06), Turkey (96-06), Sweden (83-06), UK (83-06). Eastern Europe: Bulgaria (9306), Czech Rep. (92-06), Estonia (95-06), Croatia (95-06), Hungary (92-06), Latvia (95-06), Lithuania (95-06), Poland (92-06), Romania (94-06), Slovenia (95-06), Slovak Rep. (92-06).

Figure 1 shows the striking decline of both statutory and effective tax rates since 1983. Starting in the mid 1980s with tax reforms in the UK, statutory tax rates went down considerably, whereas the effective marginal tax rates only decreased slightly due to tax base broadening. During the early 1990s, countries in northern Europe reduced their corporate tax levels by introducing some form of dual-income tax systems, which impose significantly lower tax rates on capital income relative to labor income.

Since the fall of the iron curtain, the former communist countries in Eastern Europe 
have become increasingly popular as locations for multinationals. The graphs show that the countries in Eastern Europe have significantly contributed to the overall decline of tax rates. ${ }^{2}$ In 2006, the average statutory tax rate of the 11 considered former transition economies in Eastern Europe amounted to 19.3\%. In comparison, the average of the remaining European countries was 27.5\%, a difference of 8.2 percentage points.

In the lower left-hand panel, the graph shows a less dramatic decline in effective marginal tax rates in comparison to the other tax measures. This is due to several reforms broadening the tax base, compensating for part of the cutting of statutory tax rates. Overall, the negative trend reveals that cuts in statutory tax rates have only partly been compensated by base broadening. Moreover, several countries, such as Germany in the late 1990s, have reduced the effective marginal tax rates by means of an abolishment of non-income taxes.

Regarding the evolution of tax rates over time, Figure 1 suggests that actual tax policies are strongly affected by inherited tax levels. Therefore, apart from dependence of tax rates across countries, our empirical approach to explaining corporate tax setting in Europe also considers auto-regression in tax rates.

\footnotetext{
${ }^{2}$ Note that the effective tax rates of the Eastern European countries do not reflect the various tax incentives such as tax holidays available before joining the EU.
} 


\section{Empirical approach}

\subsection{Empirical models for the corporate tax rate}

The literature has proposed various empirical models to explain corporate tax setting by national governments. Since our aim is to provide a synthesis and reassessment of the various issues discussed in previous work, we briefly discuss a number of alternative models.

Before turning to more elaborate models, it seems useful to start with a basic model that accounts only for common time effects and time-constant country characteristics. While we capture the common time effects either by a linear time trend or by a full series of period (year) effects, denoted by $\theta_{t}$, the time-invariant characteristics enter the model through country fixed effects, $c_{i}$. Our baseline model for the corporate tax rate, $\tau_{i t}$, of country $i=1, \ldots, N$ in period $t=1984, \ldots, 2006$ thus reads

$$
\tau_{i t}=\theta_{t}+c_{i}+u_{i t}
$$

where $u_{i t}$ is a residual. The next step is to include a country's openness as a measure of globalization, $g_{i t}$, providing us with the estimation equation

$$
\tau_{i t}=\gamma g_{i t}+\theta_{t}+c_{i}+u_{i t}
$$

Equation (2) allows us to check for an independent effect of openness on corporate tax rates once the impact of common shocks and country-specific effects is netted 
out. The globalization effect is expected to carry a negative sign, as a country's openness should limit the government's ability to tax mobile capital.

We then proceed by adding a number of control variables which vary over time and might therefore affect the tax rate even though time-constant country characteristics are absorbed by the fixed effects. As in most empirical studies of corporate tax setting, we include country size, measured by the log of GDP. Furthermore, the age structure of the population could influence tax policy due to budgetary effects of demographic changes. We therefore consider the fraction of young (below 15 years) and elderly (above 65 years) people as additional control variables. An increasing gap between personal and corporate income taxes may lead to an incentive to defer taxes by means of excessive retention of capital income at the corporate level. As a consequence, the corporate income tax may serve as a backstop for the personal income tax level within the tax system of a country (Slemrod, 2004), and we account for this by including the top personal income tax rate (PITR) among our controls. Denoting the vector of control variables by $x_{i t}$, the model accounting for openness, common time effects, country effects, and time-varying controls ${ }^{3}$ reads

$$
\tau_{i t}=\gamma g_{i t}+x_{i t} \beta+\theta_{t}+c_{i}+u_{i t}
$$

The next step in building a more comprehensive model for the corporate tax rate is to account for the substantial inertia in corporate tax rates by including a lagged

\footnotetext{
${ }^{3}$ We use lagged levels for GDP, openness and the variables describing the age distribution of the population to account for the time lag between the political decision regarding taxes and their actual implementation. However, using contemporary values for all control variables does not affect any of our findings.
} 
dependent variable, $\tau_{i, t-1}$,

$$
\tau_{i t}=\lambda \tau_{i, t-1}+\gamma g_{i t}+x_{i t} \beta+\theta_{t}+c_{i}+u_{i t}
$$

Note that the model now implies a dynamic adjustment to shocks as well as permanent changes in the exogenous characteristics.

Finally, the most general model that we are going to look at includes not only a country's own lagged tax rate, but also the lagged rate of neighbors. Hence, we allow for potential strategic tax competition effects. The tax competition effect is defined as a linear combination of other countries' tax rates in $t-1, \tau_{-i, t-1}=$ $\sum_{j=1}^{N} w_{i j} \tau_{j, t-1}$, with weights $w_{i j} \geq 0$ if $i \neq j$ and $w_{i j}=0$ if $i=j$, providing us with

$$
\tau_{i t}=\lambda \tau_{i, t-1}+\phi \tau_{-i, t-1}+\gamma g_{i t}+x_{i t} \beta+\theta_{t}+c_{i}+u_{i t}
$$

We expect the impact of the tax competition effect to be positive, indicating that governments adjust their own tax rate towards levels chosen by neighboring countries.

In any case, we assume $c_{i}$ and $u_{i t}$ to be i.i.d. across $i$ and $t$, independent of each other and among themselves. To purge any cross sectional or time correlations from the error term is justified because the scope of the full model is to directly estimate time correlations (through the lagged dependent variable) and spatial correlations (through the spatial variable). 
To obtain the long-run representation of the full model, we first rewrite (5) in the following form

$$
\tau_{t}=(\lambda I+\phi W) \tau_{t-1}+\gamma g_{t}+x_{t} \beta+\theta_{t}+c+u_{t}
$$

where $\tau_{t}, \tau_{t-1}, g_{t}, \theta_{t}, c$ and $u_{t}$ are $N \times 1$ vectors, $x_{t}$ is a $N \times 4$ matrix and $W$ is a $N \times N$ matrix. By recursive substitution, one can solve backwards to obtain

$$
\tau_{t}=(\lambda I+\phi W)^{t} \tau_{0}+\sum_{s=0}^{t-1}(\lambda I+\phi W)^{s}\left(\gamma g_{t}+x_{t} \beta+\theta_{t}+c+u_{t}\right)
$$

We refer the reader to Korniotis (2008) for a detailed discussion of the long-run representation. For our purpose, it is most important to note that, along with a number of regularity assumptions on $W$, we need to assume $|\lambda|+|\phi|<1$ in order to make sure that $\tau_{t}$ is stationary. The analogous assumption for model (4) is that the parameter of the lagged dependent variable is smaller than one in absolute value.

\section{$3.2 \quad$ Econometric issues}

Since the estimation of models (1) to (3) is straightforward, we focus on the econometric issues when estimating the dynamic models displayed as Equations (4) and (5). Unfortunately, we are not aware of an estimation approach for unbalanced panels solving all identification problems in a dynamic model accounting for both fixed and spatial effects. The first thing to note is that for finite $T$ the fixed effects 
(FE) estimator is not consistent in autoregressive panel data models. However, as first discussed by Nickell (1981) for the case of the autoregressive model without a spatial effect, the bias diminishes as $T$ grows, and the same holds for the more general model with cross-sectional dependence (Korniotis, 2008). Since we are using a long unbalanced panel with 24 out of 32 countries contributing a minimum of 15 annual observations to the data set, ${ }^{4}$ we expect the Nickel-bias of the FE estimator to be modest.

As alternative estimators, we considered a variety of instrumental variables (IV) procedures to estimate dynamic panel data models in the tradition of Anderson and Hsiao (1982) and Arellano and Bond (1991) as well as FE estimators with bias correction as suggested by Bruno (2005) and Korniotis (2008). Noting that IV estimators are biased in final samples, choosing between Anderson and Hsiao (1982) or Arellano and Bond (1991) as opposed to the FE estimator boils down to an efficiency tradeoff between estimators known to be biased. Generally, we found that, after taking first differences to wipe out the country-specific effects, using $\tau_{-i, t-2}$ as an IV for neighbors taxes, $\Delta \tau_{-i, t-1}$, seemed to work reasonably well. However, neither lagged tax rates nor lagged differences performed sufficiently well as IVs for $\Delta \tau_{i, t-1}$, leaving us with first-stage $F$-statistics well below 10. Taking into account Monte Carlo evidence suggesting that the IV-estimators may suffer from substantial bias when $N$ is small (Judson and Owen, 1999), we came to the conclusion that in our application the FE estimator was the better choice. Among

\footnotetext{
${ }^{4}$ The country with the fewest observations (10) is Turkey. 13 countries contribute the maximum of 23 observations.
} 
the bias-correction approaches, only Korniotis (2008) can deal with both a lagged dependent variable and a spatial effect. Unfortunately, the estimator can be applied only to balanced panels and is therefore of limited interest for this study. ${ }^{5}$

Hence, after weighting all options, we selected the FE estimator as our preferred procedure to estimate the various models presented above. With respect to model (4), we cross-checked the results from the FE estimator with those obtained from the least squares dummy variable (LSDV) procedure with bias correction proposed by Bruno (2005), finding very similar results. As a robustness check for the estimation of the full model (5), we also ran FE IV estimations, treating $\tau_{-i, t-1}$ as an endogenous explanatory variable. For details, in particular regarding the choice of the IVs, we refer the reader to Section 4.

\subsection{Data and spatial weights}

Our database covers up to 32 European countries for the period from 1983 until 2006. Basically, our sample size depends on the availability of reliable tax data. Therefore, during the 1980s the sample consists of Western and Northern European countries. Thereafter, the sample grows significantly. Beginning with 1996, it covers 32 European countries, including all current $27 \mathrm{EU}$ member states. This database constitutes by far the most extensive panel of European countries among

\footnotetext{
${ }^{5}$ We checked the performance of the Korniotis estimator on the balanced panel of those 13 European countries which are present in our data for the whole period 1983-2006. We could not come up with a specification showing a minimum robustness across a number of choices for technical parameters. This does not come as a surprise given that Korniotis (2008) is an extension of less general estimators for settings with both $N$ and $T$ being large.
} 
all existing studies on corporate tax setting. Note also that our study is the first one that, starting with 1992, includes an extensive number of countries in Central and Eastern Europe.

The choice of meaningful tax measures is essential for our purpose. If governments engage in competition for mobile capital, firms, and paper profits, they should use those tax instruments which affect the behavior of the relevant economic agents. Firms typically consider expected future tax payments rather than historical tax payments when deciding on investments or profit assignments. Therefore, we use so-called forward-looking tax rates which convey information on expected future tax payments. The three different indicators are the statutory tax rate $(S T R)$, the effective marginal tax rate $(E M T R)$, and the effective average tax rate $(E A T R)$. The $S T R$ is the simplest forward-looking indicator. However, it neglects any difference in the tax base and the existence of non-income taxes. We utilize the statutory headline tax rate of the corporate income tax adjusted to surcharges and typical local income taxes, which are imposed on the same or a similar tax base. Effective tax rates are more complex and compress various aspects of the legal tax code at a respective location. The underlying idea is to determine effective tax levels of a hypothetical, standardized investment project. An advantage of using effective tax rates is that several relevant components of the tax system of a given country can be considered within one indicator. These tax measures reflect all relevant income and non-income taxes imposed on corporate investments, as well as all the rules determining the tax base such as depreciation rules. Our specifications for 
computing the effective tax rates are similar to the assumptions in a comprehensive study about company taxation by the European Commission (2001). ${ }^{6}$

Note that the $S T R$ is a good measure in cases where it is not relevant for firms how the tax base is being determined. Therefore, it is a well-suited indicator for competition for mobile paper profits. Since the EMTR indicates the tax burden attributable to marginal investments, this measure is relevant when countries compete for marginal capital investments. Finally, the EATR is the relevant indicator of the tax burden of profitable projects that generate economic rents due to firmspecific assets. ${ }^{7}$ Consequently, the EATR should be the relevant tax measure if countries compete for complete firms or subsidiaries. ${ }^{8}$ Tax policies can asymmetrically affect these three tax measures by choosing different tax types, statutory tax rates and rules determining the tax base. Accordingly, governments are able to engage in different dimensions of tax competition. We will therefore use the STR, the EMTR, and the EATR as alternative dependent variables.

With respect to openness, we use a common trade-based measure, namely the sum of imports and exports divided by GDP. We also experimented with a variety of alternative measures, among them measures related to FDI flows relative to a

\footnotetext{
${ }^{6}$ The standardized project contains investments in the following five asset types: industrial buildings, machineries, intangible assets, inventories, and financial assets. The project is equally financed by retained earnings, the issue of new shares, and debt. We assume an incorporated company. Only domestic taxes and only income and non-income taxes imposed at the corporate level are considered. Specific property taxes on real estate and special tax regimes available only to specific firms are not included. With regard to taxable bases, we consider the relevant rules concerning depreciation allowances, valuation of inventories and interest deductibility in case of debt financing.

${ }^{7}$ As European Commission (2001), we assume a pre-tax rate of return of about $20 \%$.

${ }^{8}$ Previous empirical studies confirm that the EATR is a suitable indicator in case of location decisions (Devereux and Griffith, 1998; Büttner and Ruf, 2007).
} 
Table 1: Descriptive Statistics

\begin{tabular}{llccccc}
\hline Variable & Definition & Nob & Mean & Std.Dev. & Min. & Max. \\
\hline STR & Statutory corporate income tax rate & 571 & 0.343 & 0.102 & 0.100 & 0.631 \\
EMTR & Effective marginal tax rate & 571 & 0.231 & 0.097 & -0.196 & 0.507 \\
EATR & Effective average tax rate & 571 & 0.302 & 0.084 & 0.104 & 0.555 \\
$\sum_{j} w_{i j} S T R_{j}$ & Average of other countries' STR & 571 & 0.354 & 0.070 & 0.202 & 0.567 \\
$\sum_{j} w_{i j} E M T R_{j}$ & Average of other countries' EMTR & 571 & 0.238 & 0.066 & 0.011 & 0.475 \\
$\sum_{j} w_{i j} E A T R_{j}$ & Average of other countries' EATR & 571 & 0.310 & 0.059 & 0.177 & 0.502 \\
Openness & Sum of exp. and imp. as \% of GDP & 571 & 0.928 & 0.459 & 0.357 & 3.02 \\
PITR & Personal top income tax rate & 567 & 0.475 & 0.115 & 0.160 & 0.800 \\
GDP & GDP in billions (PPP) & 568 & 306 & 437 & 4.56 & 2197 \\
\% young & \% population <15 years & 571 & 0.186 & 0.031 & 0.135 & 0.324 \\
\% old & \% population $>$ 65 years & 571 & 0.143 & 0.023 & 0.046 & 0.199 \\
\hline
\end{tabular}

Unbalanced panel (32 countries, years 1984-2006). Tax variables based on own calculations. Underlying tax information is from several databases provided by the International Bureau of Fiscal Documentation (IBFD), Amsterdam, and from annual surveys by Ernst\&Young, PwC and KPMG. Information on FDI flows is from the World Development Indicators of the World Bank. The other control variables are from Eurostat and the World Development Indicators of the World Bank.

country's GDP as well as the Chinn-Ito financial openness index. We comment on the performance of these alternative measures in the results section.

Table 1 depicts descriptive statistics for the tax data as well as the explanatory variables discussed above.

With regard to the spatial weights, note first that when estimating Equation (5) the weights $w_{i j}$ have to be treated as predetermined. This poses the question of how to specify a metric that provides us with suitable weights. Previous studies of international tax competition have extensively employed uniform weights, which put equal weight on each foreign country in computing the average tax rate of other countries (Devereux et al., 2008; Redoano, 2007). One conceptual problem of uniform weights is that for $N \rightarrow \infty, \sum_{j} w_{i j} \tau_{j, t-1}$ becomes perfectly collinear to a common period effect. Thus, in general, with uniform weights we cannot identify 
the tax competition effect separately from a common period-specific shock. The same argument holds if other countries' tax rates are weighted by some country characteristic such as GDP or population. Since common period-specific shocks such as, for instance, changing expectations regarding the world business cycle, may be important factors shaping governments' tax policies, we are well advised to choose weights which allow for a separate identification of tax competition effects.

Given the concerns mentioned above, we define weights that are based on geographical distance. The literature provides clear-cut evidence for a negative effect of distance on FDI (e.g., see Carr et al., 2001). In case of investment decisions, geographical distance drives transportation costs for produced goods but also information costs (Portes and Rey, 2005). Geographical distance should also negatively affect pure paper-profit shifting since the underlying intra-firm transactions such as intra-firm trade should be inversely related to geographical distance as well. Therefore, it seems reasonable to assume that governments perceive tax policies of immediate neighbors to be more relevant than tax policies of more distant countries. Moreover, to ensure that the contribution of very small countries like Luxembourg or Malta is discounted relative to big countries like France or Germany (holding distance fixed), we adjust the weights by country size in terms of total population. Denoting the geographical distance between countries $i$ and $j$ (in kilometers) by $d_{i j}$ and total population by рор (in millions), we operationalize the above arguments 
by setting $w_{i j}=0$ if $j=i$ and

$$
w_{i j}=\frac{\ln \left(\text { oop }_{j}+1\right) / d_{i j}^{2}}{\sum_{k \neq i} \ln \left(\text { pop }_{k}+1\right) / d_{i k}^{2}} \quad \forall j \neq i .
$$

\section{Results}

We will discuss the findings from estimations of the various models for the statutory tax rate first. Later on, we will report corresponding results for the EMTR and the EATR, and we will also discuss a number of robustness checks and tests.

\subsection{Main results}

The results from estimations of the models (1) and (2) using the statutory tax rate as the dependent variable are reported in Table 2. Column (1) has only a linear time trend (apart from a full series of country-specific effects). The result shows that, assuming that statutory tax rates in the period under consideration are driven by a common linear time trend, governments cut the statutory tax rate by one percentage point per year on average. Column (2) allows for more flexibility in common time effects by using a full series of year effects instead of a time trend. Although the model is certainly simplistic, it is revealing to see the year effects become significantly different from zero starting in 1989. By then, the average government had reduced its statutory rate by almost 5.8 percentage points relative to the level in 1984. By 1993, the average rate had been lowered by 10.7 
Table 2: The impact of common effects and openness on statutory tax rates, 1984-2006

\begin{tabular}{|c|c|c|c|c|c|c|}
\hline \multirow{4}{*}{$\begin{array}{l}\text { Openness } \\
\text { Time trend } \\
\text { Year effects: }\end{array}$} & \multirow{2}{*}{$\begin{array}{c}(1) \\
-\end{array}$} & \multicolumn{2}{|c|}{$(2)$} & (3) & \multicolumn{2}{|c|}{$(4)$} \\
\hline & & \multicolumn{2}{|c|}{-} & $-0.095^{\star} \quad(0.049)$ & $-0.124^{\star \star}$ & $(0.053)$ \\
\hline & $-0.010^{\star \star \star}(0.001)$ & \multirow{2}{*}{\multicolumn{2}{|c|}{-}} & $-0.008^{\star \star \star} \quad(0.001)$ & \multirow{2}{*}{\multicolumn{2}{|c|}{-}} \\
\hline & & & & & & \\
\hline 1985 & - & 0.000 & $(0.009)$ & - & 0.006 & $(0.009)$ \\
\hline 1986 & - & -0.015 & $(0.014)$ & - & -0.007 & $(0.014)$ \\
\hline 1987 & - & -0.021 & $(0.016)$ & - & -0.024 & $(0.017)$ \\
\hline 1988 & - & -0.024 & $(0.017)$ & - & -0.028 & $(0.017)$ \\
\hline 1989 & - & $-0.058^{\star \star}$ & $(0.023)$ & - & $-0.060^{\star \star}$ & $(0.023)$ \\
\hline 1990 & - & $-0.071^{\star \star \star}$ & $(0.022)$ & - & $-0.064^{\star \star \star}$ & $(0.022)$ \\
\hline 1991 & - & $-0.090^{\star \star \star}$ & $(0.028)$ & - & $-0.084^{\star \star \star}$ & $(0.029)$ \\
\hline 1992 & - & $-0.086^{\star \star \star}$ & $(0.029)$ & - & $-0.090^{\star \star \star}$ & $(0.029)$ \\
\hline 1993 & - & $-0.107^{\star \star \star}$ & $(0.029)$ & - & $-0.104^{\star \star \star}$ & $(0.030)$ \\
\hline 1994 & - & $-0.112^{\star \star \star}$ & $(0.030)$ & - & $-0.110^{\star \star \star}$ & $(0.030)$ \\
\hline 1995 & - & $-0.122^{\star \star \star}$ & $(0.029)$ & - & $-0.114^{\star \star \star}$ & $(0.030)$ \\
\hline 1996 & - & $-0.122^{\star \star \star}$ & $(0.029)$ & - & $-0.115^{\star \star \star}$ & $(0.029)$ \\
\hline 1997 & - & $-0.120^{\star \star \star}$ & $(0.029)$ & - & $-0.110^{\star \star \star}$ & $(0.029)$ \\
\hline 1998 & - & $-0.130^{\star \star \star}$ & $(0.028)$ & - & $-0.114^{\star \star \star}$ & $(0.028)$ \\
\hline 1999 & - & $-0.139^{\star \star \star}$ & $(0.028)$ & - & $-0.122^{\star \star \star}$ & $(0.027)$ \\
\hline 2000 & - & $-0.153^{\star \star \star}$ & $(0.028)$ & - & $-0.136^{\star \star \star}$ & $(0.027)$ \\
\hline 2001 & - & $-0.168^{\star \star \star}$ & $(0.028)$ & - & $-0.137^{\star \star \star}$ & $(0.028)$ \\
\hline 2002 & - & $-0.182^{\star \star \star}$ & $(0.028)$ & - & $-0.152^{\star \star \star}$ & $(0.028)$ \\
\hline 2003 & - & $-0.191^{\star \star \star}$ & $(0.028)$ & - & $-0.167^{\star \star \star}$ & $(0.027)$ \\
\hline 2004 & - & $-0.203^{\star \star \star}$ & $(0.028)$ & - & $-0.180^{\star \star \star}$ & $(0.027)$ \\
\hline 2005 & - & $-0.217^{\star \star \star}$ & $(0.029)$ & - & $-0.189^{\star \star \star}$ & $(0.028)$ \\
\hline 2006 & - & $-0.222^{\star \star \star}$ & $(0.029)$ & - & $-0.189^{\star \star \star}$ & $(0.029)$ \\
\hline$N$ & 571 & 57 & & 569 & 56 & \\
\hline$R^{2}$ (within) & 0.547 & 0.5 & & 0.565 & 0.5 & \\
\hline
\end{tabular}

Fixed effects estimation using unbalanced panel of 32 countries. Standard errors (robust to heteroscedasticity and serial correlation) in parentheses. Significance levels: ${ }^{\star} 10 \%,{ }^{\star \star} 5 \%,{ }^{\star \star \star} 1 \%$.

percentage points. By the end of the time period under consideration, the average accumulated cut in statutory rates was 22.2 percentage points. Note that the $R^{2}$ from the mean-deviated regression attains the somewhat remarkable values of 0.55 in Column (1) and 0.56 in Column (2). Hence, after netting out pure cross-country variation, a linear trend or a series of year effects is able to explain between 55 and 56 percent of the remaining variation in statutory tax rates.

Columns (3) and (4) add our trade-based openness measure. Assuming that model (2) is appropriate to explain corporate tax setting in Europe, the estimated coeffi- 
Table 3: Dynamic estimation with additional country characteristics, 1984-2006

\begin{tabular}{lcccc}
\hline & $(1)$ & $(2)$ & $(3)$ & $(4)$ \\
\hline Lagged own tax rate & - & - & $0.724^{\star \star \star}$ & $0.729^{\star \star \star}$ \\
Openness & & & $(0.030)$ & $(0.033)$ \\
& -0.046 & $-0.072^{\star \star}$ & -0.005 & -0.012 \\
Top income tax rate & $(0.031)$ & $(0.035)$ & $(0.017)$ & $(0.019)$ \\
& $0.408^{\star \star}$ & $0.364^{\star \star}$ & $0.161^{\star \star}$ & $0.136^{\star \star}$ \\
$\log ($ GDP) & $(0.161)$ & $(0.159)$ & $(0.066)$ & $(0.064)$ \\
& 0.038 & 0.067 & -0.000 & 0.016 \\
$\%$ young & $(0.033)$ & $(0.043)$ & $(0.010)$ & $(0.016)$ \\
& $1.35^{\star \star \star}$ & $1.55^{\star \star \star}$ & $0.448^{\star \star \star}$ & $0.457^{\star \star}$ \\
\% old & $(0.408)$ & $(0.425)$ & $(0.160)$ & $(0.188)$ \\
Linear time trend & $2.50^{\star \star \star}$ & $2.64^{\star \star \star}$ & 0.478 & $0.538^{\star}$ \\
& $(0.827)$ & $(0.820)$ & $(0.293)$ & $(0.285)$ \\
Period effects & $-0.009^{\star \star \star}$ & - & -0.001 & - \\
$N$ & $(0.002)$ & & $(0.0007)$ & \\
$R^{2}$ (within) & no & yes & no & yes \\
\hline
\end{tabular}

Fixed effects estimation using unbalanced panel of 32 countries. Standard errors (robust to heteroscedasticity and serial correlation) in parentheses. Significance levels: ${ }^{\star} 10 \%,{ }^{\star \star} 5 \%,{ }^{\star \star \star} 1 \%$.

cient from the model including year effects indicates that an increase in the combined share of exports and imports in GDP by one percentage point would trigger a cut in the statutory tax rate by about 0.12 percentage points. We note, however, that the inclusion of openness does only marginally improve the model's $R^{2}$.

Table 3 shows the results for estimations of model (3) (first two columns) and model (4) (last two columns). We note that adding our set of control variables greatly reduces the coefficient of openness. If we account for common time effects by a linear trend, it is no longer statistically different from zero. With a full series of year effects, we find it to be -0.072 (compared to -0.124 without controls) and still significant at the 5 percent level. Among the controls, we find our expectations confirmed by noting positive coefficients of the top income tax rate, the percentage young and the percentage old. 
Returning to our key variables of interest, Columns (3) and (4) show that once we account for a lagged dependent variable, the impact of openness is reduced to virtually zero. Irrespective of whether we include a trend or year effects, we do not find any evidence supporting the notion that a country's openness affects the choice of the statutory tax rate. This finding might be questioned as being potentially driven by the specific measure for openness used here. To check the robustness of the findings reported in Columns (3) and (4), we repeated both estimations with five alternative openness measures: the share of inward FDI flows in GDP, the corresponding share for outward FDI, the combined share of inward and outward FDI, a Feldstein-Horioka type measure relating the difference between savings and investment (in absolute value) to output (GDP), and the Chinn-Ito index of financial openness. We did not find a statistically significant effect of any of these openness measures. Moreover, the trade-based measure was the only one that proved to be significant in the model reported in Column (2).

As expected, the lagged dependent variable proves to be highly significant. With a coefficient of $\hat{\lambda}=0.729$ in Column (4) of Table 3, the long-run effect of changes in the control variables can be computed by multiplying the estimated coefficients with $1 /(1-\hat{\lambda})=3.69$. For example, the long-run effect of a permanent reduction in the percentage of young by one percentage point on the statutory tax rate is predicted to be -1.69 percentage points.

It is also worth noting that the period effects in specification (4) are still significantly different from zero starting from the year 1989 (results not reported). Hence, 
even in a dynamic model using the tax rate from $t-1$ among the explanatory variables to capture the sluggish adjustment of taxes over time, we are well advised to account for common period-specific effects.

The next step is to allow for both openness and strategic tax competition to affect the statutory rate. Before turning to the full dynamic model, it is instructive to consider a static equation again. In Table 4, Columns (1) and (2), we report estimations with the lagged tax rate of neighbors and the trade-based openness measure. ${ }^{9}$ Both variables are statistically different from zero in both estimations and carry the expected sign. However, while the tax competition effect is robust to the inclusion of our control variables, the coefficient of openness drops from -0.121 to -0.058 , and is now only weakly significant. The difference between the tax competition and the globalization effect becomes even more striking once we include the lagged dependent variable, arriving at the full dynamic model displayed as Equation (5). Shown in Column (3), we note that the estimate for $\lambda$ is again highly significant and that the effect of the lagged tax rate of neighbors is positive and significantly different from zero at the five percent level, while the null of openness having no impact on statutory tax rates cannot be rejected at any reasonable level of significance. Finally, with respect to the controls, our findings qualitatively match those obtained before.

To interpret our findings in more depth, it is useful to evaluate the dynamic model in terms of the long-run effects of changes in exogenous components. This is po-

\footnotetext{
${ }^{9}$ Interestingly, the period effects become all insignificant once we account for tax competition. We report only estimations with a full series of year effects in Table 4 . The results do not vary in any significant way if we capture common time effects by a linear trend.
} 
Table 4: The role of tax competition, openness, and common effects, 1984-2006

\begin{tabular}{lcccc}
\hline & $(1)$ & $(2)$ & $(3)$ & $(4)$ \\
\hline Lagged own tax rate & - & - & $0.716^{\star \star \star}$ & $0.708^{\star \star \star}$ \\
Lagged tax rate of neighbors & & & $(0.034)$ & $(0.032)$ \\
& $\left(0.475^{\star \star}\right.$ & $0.440^{\star \star \star}$ & $0.095^{\star \star}$ & $0.155^{\star}$ \\
Openness & $-0.121^{\star \star}$ & $(0.127)$ & $(0.041)$ & $(0.091)$ \\
& $(0.052)$ & $-0.058^{\star}$ & -0.010 & -0.009 \\
Top income tax rate & - & $0.030)$ & $(0.020)$ & $(0.019)$ \\
& & $(0.159)$ & $(0.065)$ & $(0.060)$ \\
log(GDP) & - & 0.011 & 0.005 & -0.001 \\
& & $(0.040)$ & $(0.014)$ & $(0.016)$ \\
\% young & - & $1.33^{\star \star \star}$ & $0.437^{\star \star}$ & $0.425^{\star \star}$ \\
& & $(0.423)$ & $(0.194)$ & $(0.192)$ \\
& - & $2.37^{\star \star \star}$ & $0.523^{\star}$ & $0.513^{\star}$ \\
Period effects & & $(0.815)$ & $(0.288)$ & $(0.277)$ \\
Estimator & yes & yes & yes & yes \\
$N$ & FE & FE & FE & FE IV \\
$R^{2}$ (within) & 552 & 548 & 548 & 548 \\
First stage $F-S t a t i s t i c$ & 0.611 & 0.697 & 0.872 & - \\
Shea Partial $R^{2}$ & - & - & - & 81.0 \\
\hline Estimation based & - & - & - & 0.454 \\
\hline
\end{tabular}

Estimation based on unbalanced panel of 32 countries. Standard errors (robust to heteroscedasticity and serial correlation) in parentheses. Column (4) treats lagged tax rate of neighbors as endogenous, IVs are neighbors' \% young, neighbors' \% old, and neighbors' interaction between distance to Eastern Europe and count for post-1990 years (see text for details). Significance levels: ${ }^{\star} 10 \%,{ }^{\star \star} 5 \%,{ }^{\star \star \star} 1 \%$.

tentially much more involved than in a dynamic framework without cross-sectional dependence. To keep things as simple as possible, consider a case with just two countries, $i=1,2$, and a single exogenous country characteristic, $x$. Using the notation of Section 3, we then have spatial weights $w_{11}=w_{22}=0$ and $w_{12}=w_{21}=1$.

With bars now indicating that the various variables have attained their equilibrium levels, the steady-state tax rate of country 1 is determined by

$$
\bar{y}_{1}=\frac{\phi \bar{y}_{2}+\beta \bar{x}_{1}}{1-\lambda} .
$$


Substituting for $\bar{y}_{2}$ and solving for $\bar{y}_{1}$ provides us with

$$
\bar{y}_{1}=\frac{\beta(1-\lambda)}{(1-\lambda)^{2}-\phi^{2}} \bar{x}_{1}+\frac{\beta \phi}{(1-\lambda)^{2}-\phi^{2}} \bar{x}_{2} .
$$

The latter equation shows that the effect of changes in exogenous country characteristics on equilibrium tax rates depends on multipliers comprising the coefficients $\lambda$ and $\phi$. For changes in $\bar{x}_{1}$, the multiplier is $\bar{x}_{1},(1-\lambda) /\left((1-\lambda)^{2}-\phi^{2}\right)$. Substituting the estimated coefficients from Column (3) of Table 4 yields a value of 3.96. The multiplier for changes in $\bar{x}_{2}$ is $\phi /\left((1-\lambda)^{2}-\phi^{2}\right)$, which is estimated to give a value of 1.33. Hence, our estimations imply that permanent changes of relevant country characteristics have long-run effects on corporate taxes which are a multiple of the direct effects. For instance, if applied to the stylized two-country example, our model would predict a decrease of the percentage young by one percentage point in one country to have the following effects: in the short run, the statutory tax rate in the affected country will be cut by 0.44 percentage points. In the long run, the country is predicted to reduce its tax rate by 1.73 percentage points. Moreover, our model predicts also that, through the tax cuts in the affected country, the tax-reducing effect of the original shock is transmitted to the other country. In the long run, this country will reduce its own tax rate by 0.58 percentage points.

Provided that the dynamics of corporate tax setting are adequately captured in our model allowing for common time effects, openness, and tax competition, the evidence suggests a straightforward answer to the question about the determinants of the steady decline of corporate taxes in Europe. First of all, once we net out time- 
constant country characteristics and common period-specific effects, our findings do not support the notion that differences in terms of economic or financial openness affect the tax setting of countries in Europe. We do find, however, a strong impact of strategic tax competition, where governments adjust their statutory tax rate towards levels chosen in neighboring countries.

Our results point to moderate short-run effects of tax competition: with the coefficient of the tax competition effect being estimated as 0.095, the national governments are estimated to react to tax policies in other countries by directly compensating less than 10 percent of changes among competing countries. The sluggish adjustment of tax rates over time, however, leads to substantial long-run multipliers of changes in exogenous country characteristics. Moreover, our findings suggest that even if exogenous changes are limited to some countries, the interplay of tax competition and the dynamics of corporate tax setting has the potential of significantly affecting long-run equilibrium tax rates in all countries.

\subsection{Robustness and extensions}

\subsubsection{Instrumenting neighbors' taxes}

The first robustness check is concerned with the endogeneity of neighbors' taxes.

While treating the lagged dependent variable as an exogenous variable seems to be less of a problem given the considerable length of the panel, the endogeneity of the lagged tax rate of neighbors is driven also by cross-sectional dependence. 
We have constructed three IVs for neighbors' taxes and report a two-stage least squares (2SLS) estimation in Column (4) of Table 4. The IVs are lagged averages of neighbors' characteristics, constructed by applying the same set of spatial weights that was used to compute the average tax among neighbors. We select two arguably exogenous characteristics that are consistently found to be strongly related to taxes, namely the percentage of young and the percentage of elderly people. A third IV makes use of the fact that the breakdown of the communist regimes in Eastern Europe in 1989 and the fall of the iron curtain had a differential effect on Western European countries in terms of the degree of low-wage competition from Eastern Europe (Overesch and Rincke, 2009). We exploit the integration shock by constructing a count variable measuring the distance to Eastern Europe, $c_{i}$, defined as the number of countries one would have to drive through when starting in a given country's capital and heading to the physically closest capital in Eastern Europe, ${ }^{10}$ and then defining

$$
I N T 1990_{i t}= \begin{cases}0 & \text { if } t<1990 \\ -\left(5-c_{i}\right)(t-1989) & \text { if } t>=1990\end{cases}
$$

While $I N T 1990_{i t}$ for a country like Portugal with $c=5$ is flat, it assigns a scheme with a negative linear slope over time for years after 1989 to all countries closer to Eastern Europe. However, while the slope will be minus one for Spain (with $c=4$ ), it will be minus three for a country like Germany (with $c=2$ ), capturing

\footnotetext{
${ }^{10}$ In case of countries not belonging to continental Europe we count the number of countries on a straight line connecting the country's capital and the closest capital in Eastern Europe.
} 
the notion that the potential of the 1990 revolution in Eastern Europe to affect national tax policies in other countries decreases in the count $c$. Taking averages across neighbors (again using the spatial weights) provides us with a variable that is arguably exogenous to a country's own statutory tax rate but should be strongly correlated with actual tax rates of neighbors.

The results for the 2SLS regression generally support the findings from the FE estimation of the dynamic model. It turns out that the explanatory power of the IVs in the first-stage regression is impressive: the $F$-statistic for the IVs is 81.0 , and the Shea's partial $R^{2}$ equals 0.454 . While all other coefficients are almost identical to those reported in Column (3), the tax competition effect is now estimated to be 0.155 compared to 0.095 before. This suggests that the FE estimation of the dynamic model underestimates the tax competition effect. ${ }^{11}$

\subsubsection{Effective tax rates}

As discussed in Section 3, there are different ways to measure the tax burden on corporate income, with the various measures being linked to different potential dimensions of tax competition. Empirical studies dealing with the behavioral response to tax incentives suggest that multinational firms allocate profits according to differences in statutory tax rates (Hines and Rice, 1994; Huizinga and Laeven, 2008). In contrast, effective tax rates are relevant if governments compete for firms

\footnotetext{
${ }^{11}$ While using INT1990 as an additional IV improves the performance of the first-stage regression, our main result holds if we drop the average of INT1990 across neighbors from the list of IVs. The estimate for the tax competition effect becomes 0.197 (0.104), with values for the $F$-statistic of 28.7 and Shea's partial $R^{2}$ of 0.327 .
} 
and capital investment. For instance, it may be in the interest of countries to compete for multinational investment if this raises the net value of domestic production (Haaland and Wooton, 1999). Previous empirical work suggests that the EATR rather than the EMTR affects location decisions of multinationals (Devereux and Griffith, 1998; Büttner and Ruf, 2007).

Table 5 extends our analysis by reporting a selection of specifications for the EMTR and the EATR. Note that all regressions account for a full series of year effects. We find a negative impact of openness on the EMTR in a specification without any other explanatory variables, but the estimated coefficient becomes insignificant once we account for any additional regressor. However, the tax competition effect is insignificant, too, irrespective of whether we use the FE or the FE IV estimator. Hence, once we net out time-constant country characteristics and allow for common time effects, we do not find any evidence for the EMTR to be affected by openness in general or tax competition in particular.

With respect to the EATR, our findings are pretty similar. Once we allow for additional regressors, openness is not systematically related to the EATR. As long as we rely on the FE estimator, the tax competition effect is positive and highly significant and in a similar range as the corresponding effect for the statutory rate. However, once we treat neighbors' taxes as an endogenous regressor, we cannot reject the hypothesis that a country's own EATR and the average rate among neighbors are unrelated.

The extension of our analysis to cover effective tax rates thus confirms the finding 


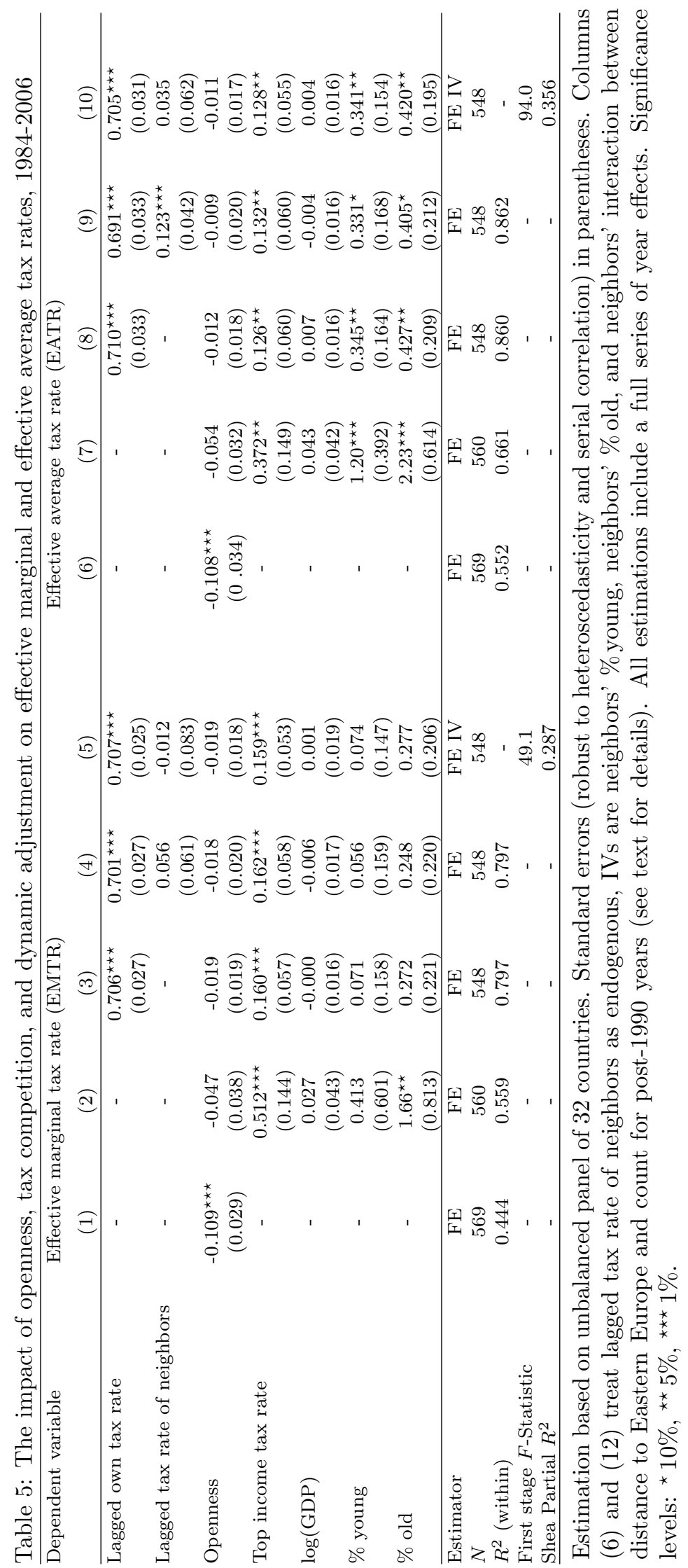


that corporate tax rates do not seem to be driven by openness. Moreover, it provides some support for the notion that governments compete for mobile firms, but it does not point to competition for marginal investments.

\subsubsection{Alternative spatial metrics}

As discussed above, using uniform weights as much of the previous literature on European tax competition is problematic as the tax competition effect cannot be identified separately from common period effects. Contiguity-based weights are not applicable without further assumptions because many countries in Europe are islands. Using some inverse function of distance this seems to be a natural choice for our application. We experimented with a number of alternative specifications, varying both the role of distance and the weighting by country size. Quite generally, we found our results to be very robust to such changes. For instance, if we drop population as a measure for country size from Equation (9), our findings are almost unchanged. The coefficients for the lagged tax rate of neighbors and openness in Table 4, respectively, change to 0.480 (0.197) and -0.120 (0.052) in Column (1), to $0.439(0.150)$ and $-0.057(0.031)$ in Column (2), to 0.108 (0.040) and -0.009 (0.020) in Column (3), and to 0.151 (0.087) and -0.008 (0.019) in Column (4). Based on the extensive search over a number of reasonable spatial metrics, we are sure that our findings are not specific to the chosen specification of the weights. 


\section{Conclusion}

Since the mid-eighties, European countries have significantly lowered their statutory and effective tax rates on corporate income. We have analyzed to what degree globalization as well as tax competition have contributed to this decline. Our empirical analysis is based on a broad sample covering up to 32 European countries for the period from 1984 until 2006. In contrast to previous studies which focused either on economic openness or on tax competition and made a number of restrictive assumptions on how to account for common period-specific effects, we estimate a series of alternative models for the setting of corporate tax rates.

Our results differ from previous work in several important respects. First of all, in contrast with several previous studies, our findings suggest that the increased economic and financial openness of countries does not contribute much to explaining the significant decline of corporate tax rates. Secondly, we find strong support for direct tax competition effects among countries with respect to statutory tax rates. In contrast, we find only weak evidence for competition over effective average and no evidence for interdependence of effective marginal tax rates. This relates our results to different dimensions of tax competition and supports the view that countries compete for paper profits and, to some extent, for firms rather than for marginal investments. In contrast to previous studies, we derive this result while allowing for a dynamic adjustment of tax rates, for general period-specific effects, and using a spatial metric that assigns to each country a specific set of neighbors. All this is done to make sure that our estimate of the tax competition effect does 
not pick up common period-specific effects.

While this is not the focus of this study, our estimations also show that once the dependence of tax rates over time and country-specific effects are controlled for, often discussed country characteristics such as GDP are not systematically related to corporate tax rates.

Taken together, our results contribute to a better understanding of the ongoing decline of corporate tax rates in Europe by showing the importance of both the direct interactions among governments and the dynamics of corporate tax policies. Most importantly, our findings suggest that the pronounced downward trend of corporate taxes cannot be explained by the presence of tax competition alone. Rather, it is the interplay of direct tax competition effects and indirect effects that work through the sluggish adjustment of the key parameters of national tax systems over time. The combination of tax competition effects and dynamic multipliers implies significant long-run effects of changes in exogenous determinants of corporate tax rates on overall tax levels. One of the consequences may be that even past shocks like, for instance, the integration of the former communistic countries in Eastern Europe, may affect corporate tax levels for many years to come.

\section{References}

Anderson, T., and C. Hsiao (1982): "Formulation and estimation of dynamic models using panel data," Journal of Econometrics, 18, 47-82.

Arellano, M., And S. Bond (1991): "Some tests of specification for panel data: 
Monte Carlo evidence and an application to employment equations," Review of Economic Studies, 58, 277-297.

Bruno, G. S. (2005): "Approximating the bias of the LSDV estimator for dynamic unbalanced panel data models," Economics Letters, 87, 361-366.

Büttner, T., And M. Ruf (2007): "Tax incentives and the location of FDI: Evidence from a panel of German multinationals," International Tax and Public Finance, 14, 151-164.

Carr, D. L., J. R. Markusen, and K. E. Maskus (2001): "Estimating the knowledge-capital model of the multinational enterprise," American Economic Review, 91, 693-708.

Davies, R. B., And J. Voget (2008): "Tax competition in an expanding European Union," Working Paper 08/30, Oxford University Centre for Business Taxation.

Devereux, M. P., And R. Griffith (1998): "Taxes and the location of production: Evidence from a panel of US multinationals," Journal of Public Economics, $68,335-367$.

(2003): "Evaluating tax policy for location decisions," International Tax and Public Finance, 10, 107-126.

Devereux, M. P., B. Lockwood, and M. Redoano (2008): "Do countries compete over corporate tax rates?," Journal of Public Economics, 92, 1210-1235.

Egger, P., M. Pfaffermayr, and H. Winner (2007): "Competition in corporate and personal income taxation," paper presented at the 2007 meeting of the European Tax Policy Forum, London.

European Commission (2001): "Company taxation in the internal market," Commission Staff Working Paper COM (2001), 582 final, Luxembourg.

HaAland, J. I., And I. Wooton (1999): "International competition for multinational investment," Scandinavian Journal of Economics, 101, 631-649.

Hines, J. R., And E. M. Rice (1994): "Fiscal paradise: Foreign tax havens and American business," Quarterly Journal of Economics, 109, 149-182.

Huizinga, H., and L. Laeven (2008): "International profit shifting within European multinationals," Journal of Public Economics, 92, 1164-1182.

Judson, R. A., And A. L. Owen (1999): "Estimating dynamic panel data models: a guide for macroeconomics," Economics Letters, 65, 9-15. 
Korniotis, G. M. (2008): "Estimating panel models with internal and external habit formation," forthcoming in: Journal of Business and Economic Statistics.

NiCKell, S. J. (1981): "Biases in dynamic models with fixed effects," Econometrica, 49(6), 1417-1426.

Overesch, M., And J. Rincke (2009): "Competition from low-wage countries and the decline of corporate tax rates - Evidence from European integration," forthcoming in: World Economy.

Portes, R., And H. Rey (2005): "The determinants of cross-border equity flows," Journal of International Economics, 65, 269-296.

Redoano, M. (2007): "Fiscal interaction among European countries. Does the EU matter?," CESifo Working Paper No. 1952.

RoDRIK, D. (1997): "Trade, social insurance, and the limits to globalization," NBER Working Paper No. 5905.

Schwarz, P. (2007): "Does capital mobility reduce the corporate-labor tax ratio?," Public Choice, 130, 363-380.

Slemrod, J. (2004): “Are corporate tax rates, or countries, converging?," Journal of Public Economics, 88, 1169-1186.

Swank, D., And S. Steinmo (2002): "The new political economy of taxation in advanced capitalist democracies," American Journal of Political Science, 46, 642-655.

Winner, H. (2005): "Has tax competition emerged in OECD countries? Evidence from panel data," International Tax and Public Finance, 12, 667-687. 


\section{CESifo Working Paper Series}

for full list see www.cesifo-group.org/wp

(address: Poschingerstr. 5, 81679 Munich, Germany, office@cesifo.de)

2473 Lukas Menkhoff, High-Frequency Analysis of Foreign Exchange Interventions: What do we learn?, November 2008

2474 Steven Poelhekke and Frederick van der Ploeg, Growth, Foreign Direct Investment and Urban Concentrations: Unbundling Spatial Lags, November 2008

2475 Helge Berger and Volker Nitsch, Gotcha! A Profile of Smuggling in International Trade, November 2008

2476 Robert Dur and Joeri Sol, Social Interaction, Co-Worker Altruism, and Incentives, November 2008

2477 Gaëtan Nicodème, Corporate Income Tax and Economic Distortions, November 2008

2478 Martin Jacob, Rainer Niemann and Martin Weiss, The Rich Demystified - A Reply to Bach, Corneo, and Steiner (2008), November 2008

2479 Scott Alan Carson, Demographic, Residential, and Socioeconomic Effects on the Distribution of $19^{\text {th }}$ Century African-American Stature, November 2008

2480 Burkhard Heer and Andreas Irmen, Population, Pensions, and Endogenous Economic Growth, November 2008

2481 Thomas Aronsson and Erkki Koskela, Optimal Redistributive Taxation and Provision of Public Input Goods in an Economy with Outsourcing and Unemployment, December 2008

2482 Stanley L. Winer, George Tridimas and Walter Hettich, Social Welfare and Coercion in Public Finance, December 2008

2483 Bruno S. Frey and Benno Torgler, Politicians: Be Killed or Survive, December 2008

2484 Thiess Buettner, Nadine Riedel and Marco Runkel, Strategic Consolidation under Formula Apportionment, December 2008

2485 Irani Arraiz, David M. Drukker, Harry H. Kelejian and Ingmar R. Prucha, A Spatial Cliff-Ord-type Model with Heteroskedastic Innovations: Small and Large Sample Results, December 2008

2486 Oliver Falck, Michael Fritsch and Stephan Heblich, The Apple doesn't Fall far from the Tree: Location of Start-Ups Relative to Incumbents, December 2008

2487 Cary Deck and Harris Schlesinger, Exploring Higher-Order Risk Effects, December 2008 
2488 Michael Kaganovich and Volker Meier, Social Security Systems, Human Capital, and Growth in a Small Open Economy, December 2008

2489 Mikael Elinder, Henrik Jordahl and Panu Poutvaara, Selfish and Prospective: Theory and Evidence of Pocketbook Voting, December 2008

2490 Maarten Bosker and Harry Garretsen, Economic Geography and Economic Development in Sub-Saharan Africa, December 2008

2491 Urs Fischbacher and Simon Gächter, Social Preferences, Beliefs, and the Dynamics of Free Riding in Public Good Experiments, December 2008

2492 Michael Hoel, Bush Meets Hotelling: Effects of Improved Renewable Energy Technology on Greenhouse Gas Emissions, December 2008

2493 Christian Bruns and Oliver Himmler, It's the Media, Stupid - How Media Activity Shapes Public Spending, December 2008

2494 Andreas Knabe and Ronnie Schöb, Minimum Wages and their Alternatives: A Critical Assessment, December 2008

2495 Sascha O. Becker, Peter H. Egger, Maximilian von Ehrlich and Robert Fenge, Going NUTS: The Effect of EU Structural Funds on Regional Performance, December 2008

2496 Robert Dur, Gift Exchange in the Workplace: Money or Attention?, December 2008

2497 Scott Alan Carson, Nineteenth Century Black and White US Statures: The Primary Sources of Vitamin D and their Relationship with Height, December 2008

2498 Thomas Crossley and Mario Jametti, Pension Benefit Insurance and Pension Plan Portfolio Choice, December 2008

2499 Sebastian Hauptmeier, Ferdinand Mittermaier and Johannes Rincke, Fiscal Competition over Taxes and Public Inputs: Theory and Evidence, December 2008

2500 Dirk Niepelt, Debt Maturity without Commitment, December 2008

2501 Andrew Clark, Andreas Knabe and Steffen Rätzel, Boon or Bane? Others' Unemployment, Well-being and Job Insecurity, December 2008

2502 Lukas Menkhoff, Rafael R. Rebitzky and Michael Schröder, Heterogeneity in Exchange Rate Expectations: Evidence on the Chartist-Fundamentalist Approach, December 2008

2503 Salvador Barrios, Harry Huizinga, Luc Laeven and Gaëtan Nicodème, International Taxation and Multinational Firm Location Decisions, December 2008

2504 Andreas Irmen, Cross-Country Income Differences and Technology Diffusion in a Competitive World, December 2008 
2505 Wenan Fei, Claude Fluet and Harris Schlesinger, Uncertain Bequest Needs and LongTerm Insurance Contracts, December 2008

2506 Wido Geis, Silke Uebelmesser and Martin Werding, How do Migrants Choose their Destination Country? An Analysis of Institutional Determinants, December 2008

2507 Hiroyuki Kasahara and Katsumi Shimotsu, Sequential Estimation of Structural Models with a Fixed Point Constraint, December 2008

2508 Barbara Hofmann, Work Incentives? Ex Post Effects of Unemployment Insurance Sanctions - Evidence from West Germany, December 2008

2509 Louis Hotte and Stanley L. Winer, The Demands for Environmental Regulation and for Trade in the Presence of Private Mitigation, December 2008

2510 Konstantinos Angelopoulos, Jim Malley and Apostolis Philippopoulos, Welfare Implications of Public Education Spending Rules, December 2008

2511 Robert Orlowski and Regina T. Riphahn, The East German Wage Structure after Transition, December 2008

2512 Michel Beine, Frédéric Docquier and Maurice Schiff, International Migration, Transfers of Norms and Home Country Fertility, December 2008

2513 Dirk Schindler and Benjamin Weigert, Educational and Wage Risk: Social Insurance vs. Quality of Education, December 2008

2514 Bernd Hayo and Stefan Voigt, The Relevance of Judicial Procedure for Economic Growth, December 2008

2515 Bruno S. Frey and Susanne Neckermann, Awards in Economics - Towards a New Field of Inquiry, January 2009

2516 Gregory Gilpin and Michael Kaganovich, The Quantity and Quality of Teachers: A Dynamic Trade-off, January 2009

2517 Sascha O. Becker, Peter H. Egger and Valeria Merlo, How Low Business Tax Rates Attract Multinational Headquarters: Municipality-Level Evidence from Germany, January 2009

2518 Geir H. Bjønnes, Steinar Holden, Dagfinn Rime and Haakon O.Aa. Solheim, ,Large’ vs. ,Small' Players: A Closer Look at the Dynamics of Speculative Attacks, January 2009

2519 Jesus Crespo Cuaresma, Gernot Doppelhofer and Martin Feldkircher, The Determinants of Economic Growth in European Regions, January 2009

2520 Salvador Valdés-Prieto, The 2008 Chilean Reform to First-Pillar Pensions, January 2009 
2521 Geir B. Asheim and Tapan Mitra, Sustainability and Discounted Utilitarianism in Models of Economic Growth, January 2009

2522 Etienne Farvaque and Gaël Lagadec, Electoral Control when Policies are for Sale, January 2009

2523 Nicholas Barr and Peter Diamond, Reforming Pensions, January 2009

2524 Eric A. Hanushek and Ludger Woessmann, Do Better Schools Lead to More Growth? Cognitive Skills, Economic Outcomes, and Causation, January 2009

2525 Richard Arnott and Eren Inci, The Stability of Downtown Parking and Traffic Congestion, January 2009

2526 John Whalley, Jun Yu and Shunming Zhang, Trade Retaliation in a Monetary-Trade Model, January 2009

2527 Mathias Hoffmann and Thomas Nitschka, Securitization of Mortgage Debt, Asset Prices and International Risk Sharing, January 2009

2528 Steven Brakman and Harry Garretsen, Trade and Geography: Paul Krugman and the 2008 Nobel Prize in Economics, January 2009

2529 Bas Jacobs, Dirk Schindler and Hongyan Yang, Optimal Taxation of Risky Human Capital, January 2009

2530 Annette Alstadsæter and Erik Fjærli, Neutral Taxation of Shareholder Income? Corporate Responses to an Announced Dividend Tax, January 2009

2531 Bruno S. Frey and Susanne Neckermann, Academics Appreciate Awards - A New Aspect of Incentives in Research, January 2009

2532 Nannette Lindenberg and Frank Westermann, Common Trends and Common Cycles among Interest Rates of the G7-Countries, January 2009

2533 Erkki Koskela and Jan König, The Role of Profit Sharing in a Dual Labour Market with Flexible Outsourcing, January 2009

2534 Tomasz Michalak, Jacob Engwerda and Joseph Plasmans, Strategic Interactions between Fiscal and Monetary Authorities in a Multi-Country New-Keynesian Model of a Monetary Union, January 2009

2535 Michael Overesch and Johannes Rincke, What Drives Corporate Tax Rates Down? A Reassessment of Globalization, Tax Competition, and Dynamic Adjustment to Shocks, February 2009 